PROCEEDINGS OF THE PREHISTORIC
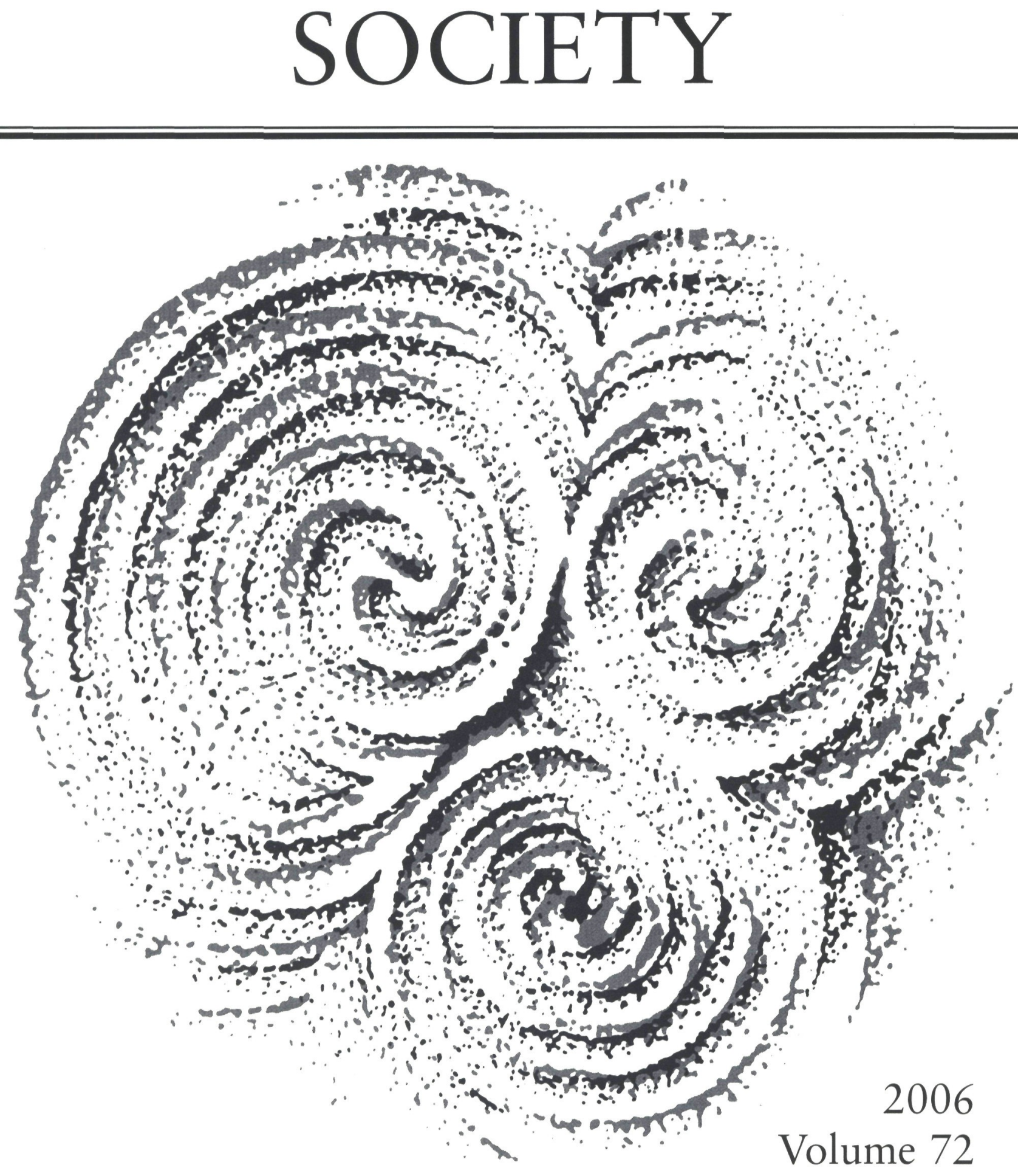


\section{THE PREHISTORIC SOCIETY}

THE SOCIETY promotes interest in prehistoric archaeology, encourages and engages in research, and disseminates knowledge of prehistory. Meetings are held in London between October to March, with a full programme of lectures at other centres around the country. Other activities include conferences, field excursions and study tours, the last held both in Britain and abroad. The Proceedings are published annually.

MEMBERSHIP. Applications for membership, subscriptions and changes of address should be sent to the Membership Secretary, The Prehistoric Society, University College London, Institute of Archaeology, 31-34 Gordon Square, London WC1H OPY, England. Subscriptions are due on 1 January.

SUBSCRIPTION RATES:

$\begin{array}{ll}\text { Individual } & £ 35 \\ \text { Institutional } & £ .50 \\ \text { Joint } & £ 40 \\ \text { Student } & £ 17.50 \\ \text { Retired, receiving Proceedings } & £ 25 \\ \text { Retired, not receiving Proceedings } & £ 12.50\end{array}$

PROCEEDINGS. All communications concerning the publication of papers and notes in the Proceedings should be sent to Dr Julie Gardiner, Wessex Archaeology, Portway House, Old Sarum Park, Salisbury SP4 6EB, England, j.gardiner@wessexarch.co.uk. All contributors are encouraged to consult the Editor at an early stage in the preparation of papers and to obtain detailed instructions to contributors.

Books for review and periodicals for exchange should be sent to the Reviews Editor, Dr M. Allen, Wessex Archaeology, Portway House, Old Sarum Park, Salisbury SP4 6EB.

Communications on other matters such as back numbers (see inside back cover for details), the insertion of leaflets, non-receipt of the Proceedings and permission to reproduce illustrative material from the Proceedings should be addressed to the Administrative Assistant (address below).

COPYRIGHT in the Proceedings rest with the Society. The Society will permit, without the need for specific authorization or payment of a fee, photocopying of

i. single copies of individual papers or sections of the Proceedings for the private use of individual researchers;

ii. single copies of individual papers or section of the Proceedings for library reserve or short-term loan use;

iii. multiple copies of individual papers or sections of the Proceedings for teaching use, provided that such copies are taken for a non-profit-making institution for educational use within that institution only.

This consent does not extend to copying for general distribution, advertising or promotional purposes, the creation of new collective works, or resale.

RESEARCH FUND. The Society hopes to make one or more awards from the Research Fund in 2007. Applications will be considered from members carrying out research into prehistoric archaeology anywhere in the world. Application forms are available from the Administrative Assistant, The Prehistoric Society, University College London, Institute of Archaeology, 31-34 Gordon Square, London WC1H OPY, England email: prehistoric@ucl.ac.uk. The closing date for applications for 2007 is 1 January 2007.

PUBLICATION GRANTS. All papers submitted to the Proceedings are considered entirely on merit but all authors are encouraged to seek funding wherever possible to help offset the cost of production.

The views expressed by the authors are not necessarily those of the Editor or Society.

The Prehistoric Society Website is : http:www.ucl.ac.uk/prehistoric/ 


\section{PROCEEDINGS OF THE PREHISTORIC SOCIETY \\ VOLUME 72}

EDITED BY

JULIE GARDINER, B.A., Ph.D., F.S.A., M.I.F.A.

Wessex Archaeology

Salisbury

\section{EDITORIAL ADVISORY COMMITTEE}

G. BARKER

T. CHAMPION

J. CHAPMAN

A. DAVID

C. FRENCH

C. Gamble

D. R. HARRIS

F. HEALY

A. SAVILle

A. SHERIDAN

G. J. WAINWRIGHT 


\section{COUNCIL OF THE PREHISTORIC SOCIETY 2006}

President: To June 2006

From June 2006

Vice-Presidents

Secretary

Treasurer

Editor

Editor, Newsletter

Conservation Co-ordinator

Meetings Secretary

Membership Secretary Administrative Assistant

Council
M. Aldhouse-Green, B.A., M. LIT., Ph.D

C. L. N. RugGLES, M.A., D.Phil., F.S.A.

R. H. BEWLEY, B.A., M.Phil., Ph.D., M.I.F.A., F.S.A.

D. MCOMISH, B.SC., F.S.A.ScOt

M. PARKer-Pearson, B.A., Ph.D., F.S.A., M.I.F.A.

A. W. R. WhiTTLE, M.A., D.phil., F.S.A.

A. GIBSON, B.A., Ph.D., F.S.A.

A. AinsworTH, B.A., A.C.M.A

J. P. GARDiner, B.A., Ph.D., F.S.A., M.I.F.A.

J. BRÜCK, M.A., Ph.D.

R. JOHNSTON, B.A., Ph.D.

D. MCOMISH, B.Sc., F.S.A.Scot

T. C. S. MACHLING, B.A.

M. J. Allen, B.Sc, Ph.D., M.I.F.A., F.L.S., F.S.A

A. BARClAY, B.Sc., Ph.D.

K. BROPHY, B.Sc., Ph.D., F.S.A.scot

P. Clay, B.A., Ph.D.

C. CONNELler, M.A, Ph.D.

M. EDMONDS, B.A., Ph.D.

P. GARWOOD, B.A., M.Sc.

M.C. GILES, B.A., M.A., Ph.D.

A. GWILT, B.A.

G. Halliwell, B.Sc.

M. Hamilton, B.A., Ph.D.

B. HARTWELL, B.SC.

R. HOSFIELD, B.A., M.Sc., Ph.D.

J. LAST, B.A., Ph.D.

B. O'CONNOR, B.A., D.Phil. F.S.A., F.S.A. scot

PRINTED IN GREAT BRITAIN

BY DERRY PRINT LIMITED

GLAISDALE PARKWAY, BIL BOROUGH

NOTTINGHAM NG8 4JQ 


\section{CONTENTS}

1. Genes, Fossils, and Culture. An Overview of the Evidence for Neandertal-Modern Human Interaction and Admixture. By JOÃO ZILHÃo

2. A Levallois Knapping Site at West Thurrock, Lower Thames, UK: its Quaternary Context, Environment, and Age. By D.C. Schreve, P. Harding, M.J. White, D.R. Bridgland, P. Alif.n, F. Clayton, D.H. Kefen and K.E.H. Pfankman

3. Launde, a Terminal Palaeolithic Camp-site in the English Midlands and its North European Context. By LYNDEN P. COOPER

4. New AMS Dates for Palaeolithic and Mesolithic Camp Sites and Single Finds in SaxonyAnhalt and Thuringia (Germany). By JUDITH M. GRÜNBERG

5. 'Total Archaeology' and Model Landscapes: Excavation of the Great Wilbraham Causewayed Enclosure, Cambridgeshire, 1975-6. By Christopher Evans, Mark EDMONDS and Steve BoreHam

6. Excavations at a Neolithic Enclosure at Lower Luggy, near Welshpool, Powys, Wales. By Alfx GibSoN

7. Pig Hunting and Husbandry in Prehistoric Italy: a Contribution to the Domestication Debate. By Umberto Albareli. a, Antonio Tagliacozzo, Keith Dobney and Peter Rowley-Conwy

8. On the Origins and Development of Cursus Monuments in Britain. By JULIAN ThOmas

9. Beer and Bell Beakers: drinking rituals in Copper Age Inner Iberia. By Manuel. ÁngeI. Rojo-Gufrra, Rafafi. Garrido-Pena, Ínigo García-Martinez-de-Lagrán, Jordi Juan-Treserras and Juan Carlos Matamala

10. Argonauts of the North Sea - a Social Maritime Archaeology for the 2nd Millennium BC. By ROBERT VAN DE NOORT

11. Towards Familiar Landscapes? On the Nature and Origin of Middle Bronze Age Landscapes in the Netherlands. By STIJN ArNOI.Dussen and DAvid FonTIJN

12. Beacon on the Ridge. Rock Carvings at Kasen Lövåsen, Bohuslän, Sweden. By JOHN COLES

13. Monuments and Memories Set in Stone: a Cornish Bronze Age Ceremonial Complex in its Landscape (on Stannon Down). By ANDY M. JONES

14. Ironworking in the Bronze Age? Evidence from a 10th century BC Settlement at Hartshill Copse, Upper Bucklebury, West Berkshire. By Mark Collard, Timothy Darvill and Martin WatTs

15. 'Guard Chambers': an Unquestioned Assumption in British Iron Age Studies. By MARK BowdEN

French, German, and Spanish Abstracts 